\title{
Assessing Intra-Faith Cohesion in Nigeria through Group Communication: The Gombe Community Score Card Project!
}

\author{
Justine John Dyikuk* \\ Lecturer, Department of Mass Communication, University of Jos, Nigeria
}

*Corresponding Author: Justine John Dyikuk, Lecturer, Department of Mass Communication, University of Jos, Nigeria

\begin{abstract}
Commentators on religion often paint intra-faith intolerance with the brush of indoctrination of members. However, there is little data on the real issues responsible for the menace. This quantitative and qualitative survey, "Assessing Intra-Faith Cohesion in Nigeria through Group Communication: The Gombe Community Score Card Project," the outcome of an intra-faith focus group discussion which was funded by a consortium of The Kukah Centre, Development Initiative for West Africa, Tony Blair Institute for Global Change and Care International United Kingdom which the researcher was a facilitator examined the situation between Christian leaders and community members from Jeka Da Fari, Federal Low Cost and Tunfure in Gombe, Gombe State. Using the Community Score Card theoretical framework, it discovered that intra-faith conflicts are caused by poor leadership, prosperity gospel and doctrinal differences. To strengthen infra-faith cohesion, the paper advocated for leadership based on merit, mutual respect and preaching the gospel of salvation. It concluded that ensuring feedback mechanism, equity, justice and synergy between Christian leaders and their flock are indispensable infra-faith tools for Christian unity in Nigeria.
\end{abstract}

Keywords: Cohesion, Community, Communication, Group, Intra-faith

\section{INTRODUCTION}

Peace-building and social cohesion are crucial to the wellbeing and survival of every society. Wherever people live in peace, there has to be a conscious effort in fulfilling the demands of mutual respect. Despite the various attempts at infra-faith cohesion or ecumenism in Nigeria, the Church is contending with challenges which stand in the way of smooth intra-faith relations. Apart from theological differences arising from different concepts of the faith and ecumenism, the Church is faced with liturgical differences. Differences in interpretation of the scripture as well as the human limitation of sin and afflictions like sickness and death which have brought about a Pentecost movement in Nigeria that cannot be rivaled by any country in Sub-Saharan Africa tells the story more. On a more theological front, other threats to Christian unity are hierarchical and theological triumphalism which makes members of one creed to look down on those who belong to other Churches. Sadly too, the cankerworms of ethnicity and tribalism are also eating deep into the fabric of the Body of Christ. While Christians are contending with that, there is infra-faith bigotry arising from hate-preaching among various Christian groups. The scandal of infiltration of elements of politics into the Church has left Christians in Nigeria without a voice since some Christian leaders play to the gallery. Little wonder, some Christian clerics have been accused of hobnobbing with politicians and smearing the image of the Christian Association of Nigeria (CAN) (Majekodumi, 2014).

Despite efforts by the World Council of Churches (WCC), the ecumenical movement which represents over 500 million Christians in the world, to unite Christians globally (World Council of Churches, 2018), infra-faith cohesion has been a far cry. Giving a keynote address titled, "Challenges facing the ecumenical movement in the $21^{\text {st }}$ century" at the Interchurch Centre in New York on 22 October, 2005, the General Secretary of WCC, Dr. Samuel Kobia highlighted the global challenges militating against the unity of Christians as decline in demographic strength, lack of synergy, communication barriers, lack of consensus on theological, cultural and pragmatic issues as well as the question of the spirituality of engagement. He contends that the primary challenge is how to respond to these problems and turn them into stepping stones for the unity of Christians (Kobia, 2005).

The leadership tussle within CAN, the umbrella body of all Christians in Nigeria which has the motto "That they may be one" (John 17:21) and came into limelight in 1976 to unite all Christians, is 
regrettable. It would be recalled that the body which is an offshoot of the merger between some leaders of the Christian Council of Nigeria (CCN) and the Catholic Church in Nigeria which came into being to restore the unity of Christians in the country. Unfortunately, as it stands, certain leaders within the association resort to the courts to settle their differences against biblical injunction (Omonokhua, 2018). It is, therefore, a given to say "Leadership tussle constitutes a major threat to the unity of [the] Christian community in Nigeria" (Danbaba, 2016, p.4).

The manifestation of intra-faith intolerance which often leads to rancour and disunity among Christians has made it impossible for Christians to learn the faith-values of others from a different Church. The resultant effects of this threat is widespread ignorance/illiteracy, hate preaching and radicalization. The intolerance in the country leading to various crises is a consequence of lack of knowing and implementing the basics of infra-faith relations. To stem the tide of infra-faith disharmony among Christian leaders and their adherents in the Nigeria, The Kukah Centre in collaboration with their partners, Development Initiative for West Africa, Tony Blair Institute for Global Change and Care International United Kingdom debuted various intra-faith focus group discussion workshops especially in some parts of the North under a programme, Supporting Leaders Nigeria (SLN) Project. In line with the core objectives of the Community Score Card, the aim of this study is:

- Appraising the Community Score Card strategy which was carried out between Christian leaders and community members in Jeka Da Fari, Federal Low Cost and Tunfure in Gombe, Gombe State which the researcher was a participant observer;

- Accessing feedback-mechanism for intra-faith cohesion in Gombe State;

- Equipping religious and community leaders to identify and tackle infra-faith tensions and extremism;

- Initiating counter-narratives and practical community action between clerics and their members;

- Strengthening social cohesion in the society through community and religious leaders (Muyumbu, 2018) and using the Gombe pilot study group communication project as a paradigm for intra-faith cohesion in Nigeria.

\section{THEORETICAL FRAMEWORK}

The researcher used the Community Score Card (CSC) strategy as theoretical framework for the study. The CSC strategy is a two-way and ongoing participatory tool developed by CARE International (UK) for the assessment, planning, monitoring and evaluation of services (Muyumbu, 2018). It helps Service-Users to hold Service-Providers accountable. The CSC aids in resolving the poor and unequal relations between the two. It equally assists in improving tangible services like health care, education, nutrition and peace building leading to Joint Action Plans.

Essentially, the CSC uses problem analysis, stakeholders or power analysis, gender analysis and conflict analysis to evaluate issues (Tony Blair Institute \& CARE International UK, 2018, p.2). Under problem analysis, the problem/solution-tree is used to identify the issues of a Join Community Action Plan (JCAP) focus. For instance, in the context of intra-faith relations, the reasons for religious intolerance are identified. Participants examine how religious intolerance manifest in their community and what the root causes of religious intolerance are (Muyumbu, 2018).

The next step being the stakeholders or power analyses involves identifying the main actors with an interest in the objective of the JCAP. Attempts are made to provide answers to the main objective of the JCAP, identify those with high, medium and low interests and who the perpetrators are in society as distinct from the victims.

Another crucial segment of the CSC strategy is gender analysis. This type of analysis identifies specific ways in which issues or problems affect people based on gender. Usually, the issues are scored based on their number, how they affect men as different from women, youth and children; the ideal scenario and proposed solutions are often provided to make for a balanced situation.

In conflict analysis, both stakeholders and community members revisit the various analyses based on "Do No Harm" in the light of connectors and dividers. On the one hand, dividers are considered as processes or institutions that are not subject to consensus in society. Examples are, clan structure and 
ethnicity, ideology, leadership feuds, religion to mention a few, which contribute to reinforcing divisions in the society. On the other hand, connectors are elements that connect people across subgroups. For instance, youth concerns, public space, markets, religion, politics, sports and the like. These are considered as opportunities for positive change (Muyumbu, 2018). The CSC was conducted based on these dynamics.

\section{DECONSTRUCTION OF CONCEPTS}

\subsection{Intra-Faith Cohesion}

For the purpose of this study, intra-faith cohesion is understood as the deliberate attempt by Christians to understand, tolerate, respect and relate with other Christians who do not share the same creed with them on the basis of one Lord, one faith and one baptism (Ephesians 4:5). From the ecumenical point of view, it may involve sharing of pulpit, the word of God, exchange of ideas and engaging in common projects. Infra-faith cohesion is a religious ideology which attempts to break down the walls created by doctrinal differences and theological interpretations within Christendom. It is a mechanism for interrogating fundamentalism and violent extremism among Christian groups which paves way for deradicalization and mutual trust.

Ecumenism, a word developed by the Catholic Church, is an attempt to reconcile with Christians who had become separated over theological issues towards touching the world positively (Inja, 2012, p. 198). In this paper, intra-faith cohesion, harmony and tolerance would be used with ecumenism interchangeably.

\subsection{Group Communication}

In this study, we shall conceive group communication as that interaction which takes place in small groups of three to ten or fifteen people who have common interest, goal purpose, mutual influence and shared identity. It is a kind of communication which enables everyone in the group to be able to a source and also a receiver because of the mechanisms of information-sharing and mutual-feedback (Dyikuk, 2018, p.66). The study understands the Gombe Community Score Card (CSC) Focused group discussions as group communication.

\subsection{Community Score Card (CSC)}

Community Score Card (CSC) is a two-way and ongoing participatory tool developed by CARE International (UK) for the assessment, planning, monitoring and evaluation of services with the aim of ensuring feedback, accountability and resolving unequal relations between Service-Providers and Service-Users. CSC has been used in Malawi and Kenya to improve tangible services like health care, education, nutrition leading to Joint Action Plans (JAP) (Muyumbu, 2018).

It is also "a participatory tool that which is conducted at micro/local level and uses the community as the unit of analysis, generates information through focus group interactions and enables maximum participation of the local community, provides immediate feedback to service providers and emphasizes immediate response and joint decision making and allows for mutual dialogue between users and providers and can be followed by joint monitoring" (CARE Malawi, 2013, p. 6). Accordingly, it is not about finger-pointing, blaming or designed to settle personal scores or create conflict.

\section{LITERATURE REVIEW AND DISCUSSION}

\subsection{Infra-Faith and Social Disharmony in Gombe State: Brief History and Dynamics}

In Nigeria, the issues of religion are often tied to ethnicity and politics. This is why the matrix is often complex. Little wonder, there have been cries of marginalization of minorities in Northern Nigeria. This why any infra-faith discussion that does not take into cognisance the historical context surrounding socio-cultural, economic, political religious issues is unlikely to yield results. Although this paper is dealing with intra-faith cohesion, other dynamics will play out so as to put the issue in proper context.

In the context of intra-faith disharmony or intolerance within Jeka Da Fari, Federal Low Cost and Tunfure in Gombe, the area under consideration, there has been leadership tussle in CAN. This has scandalously led to police intervention. Fighting for the soul of CAN which is often seen as a position 
for romancing with government and wielding power and not service (Gombe, CSC Participants, 2018) is fingered as responsible for the in-house fighting. While some community and Christian leaders do not openly admit of fracas in their churches, nonetheless, the ugly trend takes place. However, there is dearth of extant data on intra-faith intolerance among Christians in the area under discussion.

While contending with serious issues threatening the unity of Christians, there are other issues which stand in the way of peaceful coexistence, begging for attention. In the year 2014, an ethnic group under the auspices of Northern Minorities Rights Project in a joint memoranda submitted by their representatives at the National Conference decried that the elite in their region had systematically marginalised them and upheld unjust policies which put some Nigerians under servitude. The group listed Gombe alongside Kaduna, Niger, Kwara, Borno and Kebbi as some of the states where many groups of minority ethnic nationalities have been lumped together by powerful hegemonic groups who continue to monopolise political and economic power (Owete, 2014).

The case that was made by Gombe State CAN to the state government in 2016 for the establishment of a ministry for religious affairs and employment of Christian teachers (Uba cited in Mohammed, 2016) gives the impression that Christians are marginalised in the state. That is not to say that Christians themselves do not have their own problems. The mainly Christian Gombe South has been boiling in an age-long land dispute between the people of Kufai in Billiri Local Government Council, LGC and those of Kulushin in Shongom LGC of Gombe State. For over a decade, Dadiya, Tula, Kaltungo and Waja communities have engaged in communal clashes as a result of land disputes. The conflict started with Billiri-Kaltungo in 1991, Tula-Awak, 1999, Dadiya-Kaltungo 2007-2012 and Dadiya-Waja in 2013 (Gombe State Government Reports to Consolidate All Previous Committees' Report, 2014). This crisis has degenerated into series of unresolved communal clashes in the affected communities leading to loss of lives and properties.

\subsection{Various Interventions in the Light of Intra-Faith and Social Cohesion}

Aware of the implications of religious extremism and the dangers of intolerable narratives, The Kukah Centre (TKC), Development Initiative for West Africa (DIWA), Tony Blair Institute for Global Change (TBI) and Care International (CI), United Kingdom came up with the Supporting Leaders Nigeria (SLN) Project to identify and tackle religious extremism, initiate counter-narratives and practical community action as well as strengthen social cohesion in the society through community and religious leaders (Muyumbu, 2018). The primary objective of the pilot programme was to provide feedback between Christian leaders and their flock. The aim of the Community Score Card intra-faith focus group discussion workshop was to resolve the poor and unequal relations between ServiceProviders and Service-Users, the leaders and their flock which Dyikuk (2011) refers to as the pew and the pulpit (Dyikuk, 2011).

To successfully carry out this intervention, these partners often ensure will-power, leadership participation, objectivity and independence; audit reports, broad community participation and selection of a required project which is relevant to the large portion of the community. Other strategies include, inclusion of marginalized groups such as women and youth, ensuring that findings are widely shared, clear action plans are made with responsibilities assigned and a timeline as well as follow up on the Action Plan are in place (Tony Blair Institute \& CARE International UK, 2018, p.23).

For example, to mitigate the crisis in some parts of Gombe South, the Centre for Justice Development and Social Cohesion, CJDSC of Bauchi State, a non-governmental social agency under the aegis of the Justice Development and Peace Commission, JDPC of the Catholic Diocese of Bauchi took it upon itself to start various capacity and peace building projects. Through its planned programme and partnership with Misereor, a foreign donor agency, CJDSC embarked on various capacity and peace building projects in the identified communities of Shongom, Balanga, Kaltungo and Billiri LGCs of Gombe State. Notwithstanding these initiatives, Community Score Card was not used.

On its part, the Gombe State Government did not rest on its oars in its attempt to nip the conflicts in the bud. To this end, from 2006 various judicial commissions of inquiry and Ad-hoc committees were instituted by the government to curb the menace. There was the 2006 Judicial Commission of Inquiry, 2017 Join Peace Security Committee, Seven Man Ad-hoc Committee, 2013 Peace Mission Committee and 2014 Committee to Consolidate the Recommendations of All Previous Committees to tackle the 
clashes were initiated by the government to put an end to the conflicts. As it is, these interventions did not provide the needed respite (Joshua, 2016). This is why interventions like The Kukah Centre et al infra-faith cohesion workshops, through the Community Score Card focus group discussion strategy, may provide the needed respite as participants at the workshop suggested (Gombe, CSC Participants, 2018).

\section{LIMITATIONS OF INTRA-FAITH COHESION IN NIGERIA}

In the light of the submission of participants at the intra-faith focus group discussion Community Score Card workshop, this paper highlights five limitations which have made intra-faith harmony in Nigeria a far cry from what it should be. These are:

- Poor Leadership/Leadership Tussle: The participants were in agreement that the challenge of the Church in Nigeria is the problem of leadership which often rears its ugly head in leadership tussles. Apparently, their submission goes in line with what the cerebral Nigerian novelist, Chinua Achebe said in his book The trouble with Nigeria namely: "The trouble with Nigeria is simply and squarely a failure of leadership. There is nothing basically wrong with the Nigerian character. There is nothing wrong with the Nigerian land or climate or water or air or anything else - The Nigerian problem is the unwillingness or inability of its leaders to rise to the responsibility, to the challenge of personal example which are the hallmarks of true leadership" (Achebe, 1984, p1). Today, there is aggressive proselytizing in which each denomination is seeking for domination (Dairo, p.87). Besides that, there is also internal wrangling within the power structure of each Church.

A case in point was the leadership tussle in the Assemblies of God Church between Prof. Paul Emeka and Dr. Chidi Okoroa for over the position of General Superintendant which led to the declaration of a General Council in the North and a judicial process (Alabi, 2017 \& Ebhomele 2017). The same scenario played out when the people of God in Ahiara Diocese rejected the appointment of Most Rev. Peter Akpaleke as their Bishop which led to his resignation (Olowolagba, 2018). Recently, some members of the Anglican Communion in Lagos rejected the appointment of Rt. Rev. Henry Olumakaiye as the Bishop of Lagos over alleged bribery (24 Ureports.com, 2018). "In a society or organisation where there is poor leadership, there is bound to be confusion, disorderliness and lawlessness" (Danbaba, 2016, p.4). Failure to address this has remained a serious challenge to the unity of Christians in Nigeria.

- Theological, Doctrinal and Liturgical Difference: Based on differences in theology, doctrine and liturgy, infra-faith cohesion in Nigeria has remained on the back bench. Participants also observed that despite concerted efforts at uniting Christians both in local churches or nationally, differences in the understanding of ecumenism as well as in interpretation of doctrinal issues remain a clog in the wheel of progress. Inja (2012, p.204) opines that there is no single denomination in Christianity that has a doctrine that is not faulted by or draws controversy. Perhaps it is why some scholars hold that "doctrine divides, service unites" (Jesson, 2003, p.1).

It is instructive to note that most of these theological, doctrinal and liturgical differences the Church is facing today dates back to history. Perhaps it is why Nmah $(2015$, p.369) suggests that: "Fundamental beliefs and practices of different strands of the Church of reformation again constitute also in themselves part of the doctrinal controversy. This includes the concept of Sola Scriptura (scripture alone as the yardstick of faith), Sola Fide (faith only), the Sola Gracia (only grace as a means of salvation, the Solus Christus or the Sola Christo (the teaching that Christ is the only mediator - the only pre-eminent High Priest between God and man) and Soli Deo Gloria (glory to God only)."

- Superficial Spirituality: Both members of the community and the Christian leaders identified holier-than-thou attitude and name-calling which involves labelling other Christians as white garment Church members, blood suckers or worshippers of Mary as evidence of a superficial spirituality. They also decried the phenomenon of prosperity gospel which has become a cankerworm in the Nigerian Church. The leaders particularly stressed that prosperity gospel is used as a cover up for materialism or what is now referred to as spiritual materialism. "Spiritual materialism is a manifestation of queer capitalist tendency in the contemporary world" (Okoli \& Uhembe, 2014, p.604). 
Assessing Intra-Faith Cohesion in Nigeria through Group Communication: The Gombe Community Score Card Project!

It is not surprising that scholars argue that the manifestation of spiritual materialism in Nigeria has taken the form of materialization and commodification of spiritual providence which manifests in all religions in the country but more prominently in Christianity. The argument is sustained that over the years, the trend has found expression in various religious practices such as, proliferation of faith-based organisations, religious prebendalism (materialization and commercialization of spiritual providence), monetization of faith and grace, corporate merchandising and ostentatious religiosity (Okoli \& Uhembe, 2014, Pp. 601-602).

- Discrimination of Women: Gender issues like the discrimination of women came to the fore. Although the men seemed to suggest that the situation of discrimination of women is not rife in the Church, the women stood their grounds by insisting that segregation against them militates against intra-faith cohesion. Few instances were given where women are denied leadership in the Church because the bible says they should be silent in Church (1 Cor.14:34). At the end, the Christian leaders agreed that the Church is yet to tap the hidden potentials in women.

\section{Computation of Respondents' Data And Results}

Table1A. Community Participants Based on Gender

\begin{tabular}{|l|l|l|}
\hline \multicolumn{1}{|c|}{ Variable } & \multicolumn{1}{c|}{ Frequency } & \multicolumn{1}{c|}{ Percentage } \\
\hline Male & 16 & 66.7 \\
\hline Female & 8 & 33.3 \\
\hline Total & 24 & 100 \\
\hline
\end{tabular}

Table1B. Christian Leaders Based on Gender

\begin{tabular}{|l|l|l|}
\hline \multicolumn{1}{|c|}{ Variable } & \multicolumn{1}{c|}{ Frequency } & \multicolumn{1}{c|}{ Percentage } \\
\hline Male & 19 & 80.1 \\
\hline Female & 4 & 19.9 \\
\hline Total & 24 & 100 \\
\hline
\end{tabular}

Table1C. Community Participants Based on Church

\begin{tabular}{|l|l|}
\hline \multicolumn{1}{|c|}{ Name of Church } & \multicolumn{1}{c|}{ Number } \\
\hline Catholic & 2 \\
\hline Anglican & 7 \\
\hline Evangelical Church Wining All (ECWA) & 5 \\
\hline United Methodist Church in Nigeria (UMCN) & 3 \\
\hline United Evangelical Church (UEC) & 2 \\
\hline Baptist & 3 \\
\hline New Generation Faith Anglican Church (NGFA) & 2 \\
\hline Total & 24 \\
\hline
\end{tabular}

Table1D. Christian Leaders Based on Church

\begin{tabular}{|l|l|}
\hline \multicolumn{1}{|c|}{ Name of Church } & \multicolumn{1}{c|}{ Number } \\
\hline Catholic & 3 \\
\hline Anglican & 8 \\
\hline ECWA & 5 \\
\hline UMCN & 1 \\
\hline U E C & 3 \\
\hline Baptist & 1 \\
\hline NGFA & - \\
\hline Action & 1 \\
\hline Holy Cross & 1 \\
\hline Total & 23 \\
\hline
\end{tabular}

Summary: The survey was conducted among the 24 participants from the community which comprises of 16 males and 8 females as well as 23 Christian leaders which comprises of 19 males, 4 females that participated at the Cycle 1A Community Score Card workshop at, Jeka Da Fari, Federal Low Cost and Tunfure, Gombe, Gombe State on $2 \& 3$ July 2018. 
Assessing Intra-Faith Cohesion in Nigeria through Group Communication: The Gombe Community Score Card Project!

Table2A. Submission of Christian Community Delegates

\begin{tabular}{|l|l|l|l|l|}
\hline \multicolumn{2}{|c|}{ Issues } & \multicolumn{1}{|c|}{ Indicators } & Scores & \multicolumn{1}{c|}{ Reasons } \\
\hline 1. & Poor leadership/Leadership tussle & Leadership based on merit & 3 & $\begin{array}{l}\text { There is tolerance } \\
\text { regardless of the issue }\end{array}$ \\
\hline 2. & Holier-than-thou attitude & $\begin{array}{l}\text { Being non-judgemental and } \\
\text { accepting others }\end{array}$ & $\begin{array}{l}\text { It brings disunity to the } \\
\text { body of Christ }\end{array}$ \\
\hline 3. & $\begin{array}{l}\text { Name calling e.g White garment Church, } \\
\text { blood suckers, Mary worshippers }\end{array}$ & Mutual respect & 1 & $\begin{array}{l}\text { It brings hatred, disunity } \\
\text { and suspicion }\end{array}$ \\
\hline 4. & Prosperity gospel/materialism & $\begin{array}{l}\text { Preaching the gospel of Christ// } \\
\text { Salvation }\end{array}$ & $\begin{array}{l}\text { It brings about deviation } \\
\text { from the truth }\end{array}$ \\
\hline 5. & Doctrinal differences & Respect and tolerance & 3 & $\begin{array}{l}\text { It is not too rampant beca } \\
\text { use of tolerance and respect }\end{array}$ \\
\hline 6. & Sectionalism and tribalism & Equity, justice, merit and unity & 2 & It brings about disunity \\
\hline 7. & Poor discipleship & Good mentorship & 2 & $\begin{array}{l}\text { It leads to stagnation of } \\
\text { the faith }\end{array}$ \\
\hline 8. & Discrimination of women & Equality & 4 & \begin{tabular}{l} 
It is not rampant \\
\hline
\end{tabular}
\end{tabular}

Source: The Kukah Centre

*Score Indicator: 1. Very bad 2.Bad 3.Fair 4. Good 5. Very Good

Summary: Views of Christian Community Delegates from Jeka Da Fari, Federal Low Cost and Tunfure, Gombe, Gombe State during the Community Score Card Cycle 1A on 2 July 2018.

Table2B. Submission of Christian Leaders

\begin{tabular}{|c|c|c|c|c|}
\hline \multicolumn{2}{|r|}{ Issues } & Indicators & Scores & Reasons \\
\hline 1. & $\begin{array}{ll}\text { Poor leadership/Leadership } \\
\text { tussle }\end{array}$ & Leadership based on merit & 1 & $\begin{array}{l}\text { It brings about selfishness, rivalry, } \\
\text { intolerance and poor leadership }\end{array}$ \\
\hline 2. & Holier-than-thou attitude & $\begin{array}{l}\text { Being non-judgemental } \\
\text { and accepting others }\end{array}$ & 4 & $\begin{array}{l}\text { There is good relationship among } \\
\text { Christians }\end{array}$ \\
\hline 3. & $\begin{array}{l}\text { Name calling e.g White } \\
\text { garment Church, blood } \\
\text { suckers, Mary worshippers }\end{array}$ & Mutual respect & 3 & It is not so much pronounced \\
\hline 4. & $\begin{array}{l}\text { Prosperity } \\
\text { gospel/materialism }\end{array}$ & $\begin{array}{l}\text { Preaching the gospel of } \\
\text { Christ/Salvation }\end{array}$ & 2 & $\begin{array}{l}\text { It creates suspicion, members of the Church } \\
\text { are being exploited and prosperity gospel is } \\
\text { used as a cover up for materialism }\end{array}$ \\
\hline 5 . & Doctrinal differences & Respect and tolerance & 1 & $\begin{array}{l}\text { It brings about disunity and sheep-stealing; it } \\
\text { also produces shallow minded Christians }\end{array}$ \\
\hline 6. & Sectionalism and tribalism & $\begin{array}{l}\text { Equity, justice, merit and } \\
\text { unity }\end{array}$ & 1 & $\begin{array}{l}\text { It brings about hatred and disunity; it } \\
\text { makes people to withdraw support to the } \\
\text { Church and poor leadership }\end{array}$ \\
\hline 7. & Poor discipleship & Good mentorship & 2 & \begin{tabular}{|llll}
$\begin{array}{l}\text { Poor succession of leadership and } \\
\text { generational gap }\end{array}$ & & \\
\end{tabular} \\
\hline 8. & Discrimination of women & Equality & 3 & $\begin{array}{l}\text { We are yet to tap the hidden potentials of } \\
\text { women }\end{array}$ \\
\hline
\end{tabular}

Source: The Kukah Centre

*Score Indicator: 1. Very bad 2.Bad 3.Fair 4.Good 5. Very Good

Summary: Views of Christian Leaders from Jeka Da Fari, Federal Low Cost and Tunfure, Gombe, Gombe State during the Community Score Card Cycle 1A on 3 July 2018.

\section{Data Presentation AND ANALYSIS}

In Table 2A, the participants blamed infra-faith intolerance in Jeka Da Fari, Federal Low Cost and Tunfure of Gombe State on poor leadership and leadership tussle within the Christian community while stressing that leadership based on merit is a panacea to the problem. They scored the reason for the situation as 3 (60\% - Fair) noting that there is tolerance regardless of the issue as reason for the score.

They fingered holier-than-thou attitude as a recurrent decimal in their community and gave being nonjudgemental and accepting others as the indicator. Participants scored the situation 2 (40\% - Bad) and gave the reason for the score as, it brings disunity to the body of Christ. The community 
representatives also blamed intra-faith tensions on name-calling citing instances where some Christians label others as white Garment Church, blood suckers and worshippers of Mary. They, therefore, suggested mutual respect as the required recipe and scored the phenomenon 1 (20\% - Very Bad). They regretted that the menace brings about hatred, disunity and suspicion noting that it is the reason for the score.

Prosperity gospel and materialism were also identified as factors militating against Christian unity. Participants agreed that preaching the gospel of Christ and salvation are key to countering the anomaly but scored the occurrence as 1 (20\% - Very Bad). They gave the reason for score as, prosperity gospel and materialism brings about deviation from the truth. Their submission included doctrinal difference as a cause of Christian disunity. They recognized respect and tolerance as values that can turn things around regarding ecumenism. 3 (60\% - Fair) was given as the score for the effects of issues surrounding doctrinal difference because the phenomenon is not too rampant as a result of tolerance and respect in the community.

Other factors standing against infra-faith relations that were raised include, sectionalism and tribalism. Participants stressed that ensuring equity, justice, merit and unity are the required indicators. They scored the situation $2(40 \%$ - Bad) noting that the score is low because sectionalism and tribalism brings about disunity. Poor discipleship was not spared as another reason for intra-faith intolerance. To ensure intra-faith cohesion, participants suggested good mentorship of the young who are leaders of tomorrow while scoring the situation as low as $2(20 \%$ - Bad) because it leads to stagnation of the faith.

The last but most controversial factor standing in the way of intra-faith cohesion was identified as discrimination of women. There was a unanimous agreement that there should be equality of all as God's sons and daughters created in his image and likeness (Genesis 1:27). However, because participants considered the matter in the light of Christian unity, it was scored 4 (80\% - Good). This was because they felt that the discrimination of women in the Church is not too rampant.

In Table 2B, on the challenge of poor leadership and leadership tussle earlier raised by members of the community, the leaders proposed leadership based on merit as the perfect indicator and scored the occurrence as 1 (20\% - Very Bad) which is very bad because they regretted that it brings about selfishness, rivalry, intolerance and poor leadership. While they were in line with members of the community on the sad situation of holier-than-thou attitude as militating against Christian unity, they also agreed that being non-judgemental and accepting others remain key to intra-faith cohesion. However, they scored the situation 4 ( $8 \%$ - Good) because notwithstanding the holier-than-thou attitude, there is good relationship among Christians.

On the challenge of name-calling, they proposed mutual respect and scored the situation $3(60 \%$ Fair) because its occurrence is not so much pronounced. The Christian leaders were in agreement with members of the community that prosperity gospel and materialism leads to Christian disunity. This is why they scored the situation $2(40 \%$ - Bad) because they submitted that it creates suspicion and makes members of the Church to be exploited stressing that prosperity gospel is often used as a cover up for materialism.

Mutual respect and tolerance were given as the antidote to doctrinal differences as the score of its occurrence in the community was given as 1 ( $20 \%$ - Very Bad). It was scored so because the situation brings about disunity, leads to sheep-stealing and produces shallow minded Christians. The leaders also decried the problem of sectionalism and tribalism among Christians. They chose equity, justice, merit and unity as the indicators and marked the situation as 1 (20\% - Very Bad) because it brings about hatred and disunity, makes people to withdraw support to the Church and brings about poor leadership.

For poor discipleship, the leaders proposed good mentorship of the young as a way out. They, however, scored the situation $2(40 \%$ - Bad) because it creates poor succession of leadership and generational gap within Christendom. Like the community members, the leaders agreed that there are few cases of discrimination of women in the Church which is why they scored its occurrence $3(60 \%$ Fair) because the Church is yet to tap the hidden potentials in women.

\section{Limitation OF THE STUdY}

This paper acknowledges that the Cycle A 1 Community Score Card did not reach the phase 4 which is interface meeting and action planning (Tony Blair Institute \& CARE International UK, 2018, p.2). 
Usually, the interface involves bringing both the service-providers and service-users together. In that circumstance, Animators are selected from each of the groups to assist in observing and raising the issues of the community. This leads to The Joint Community Action Plan which rates the issues of intrafaith cohesion based on issues, resolutions, responsibility and timeline for implementation and evaluation.

Although the Gombe Jeka Da Fari, Federal Low Cost and Tunfure Community Score Card did not reach the interface and Joint Action Plan stage, the views of the participants concerning the challenges and prospects of intra-faith cohesion have provided this study with relevant data for using the pilot study as a paradigm for Nigeria. This is why this study hopes to stimulate more research in the area of study. This will further furnish students of communication, peace-studies and theology as well as relevant stakeholders with data on various intra-faith interventions in Nigeria with the view to ensuring giant ecumenical strides and peaceful coexistence in the country.

\section{RECOMMENDATIONS AND CONCLUSION}

\subsection{Recommendations}

- Having Common Worship/Prayer: To ensure infra-faith cohesion in Nigeria, through CAN, Christians can expand the opportunities for ecumenism by initiating interfaith prayer sessions where the reading of sacred texts and reflection can take place. It must not be during the prayer for Christian unity or the week following Easter Sunday alone. When there are genuine needs such as during draught, famine or death, Christians can come together to seek God's intervention.

This joint worship or prayer sessions can be four or five times a year. It must be acknowledged that this kind of ecumenical gathering requires a certain level of caution and maturity so as not to give the impression that some believers are forced to undergo a unilateral-worship. The forum should not be used to condemn others or steal sheep belonging to other churches. Where this takes place in local communities, the impact is likely to be huge as it sends a message of unity of purpose among God's children.

- Engaging in Theological Exchange: Christians from various Churches can engage in theological exchange. Those who are in the academia and pastors of souls who have the expertise as both experts and theologians can meet to clarify issues or dialogue on certain issues disturbing the Body of Christ. They can arrange quiz, debates, symposia or talk-shows for all Christians on topics such as morality or the impact of the faith in a challenging world. It is the responsibility of clerics to prepare the minds of their members to remove prejudices that may blind them from actively participating in these theological exchanges. This may help in the area of assisting Christians to appreciate each other's spiritual values while having a better understanding of their doctrinal differences. This could take the form of workshops, seminars and conferences in seminaries (Nmah, 2015, p.371).

- Initiating Common Action/Projects: Where Christians from various Churches embark on common projects such as provision of a borehole in the village or repairing a bad road, such an action makes a big statement. Christians can work together to promote justice and peace as well as the respect for life. The Holy Scripture has given God's children custody of the earth to be used for the glory of his name (Genesis 1:2). Therefore, it is only appropriate for Christians to collaborate in addressing various social concerns in their society and the world at large.

- Fraternal Correction and Mature Resolution of Conflicts: It is important for believers to embrace maturity in dealing with others. This is at the heart of fraternal correction. Where Christians from different churches resort to the police or courts to resolve differences arising from land dispute or leadership tussle in CAN, the Body of Christ suffers. As a way out, increased workshops in schools on peace building and conflict management would be a way of training the young to embrace fraternal correction and resolve consults in a mature manner.

In like manner, Christian leaders and educators have the mandate to label bullying as violence and encourage student-volunteerism on peace building skills and mutual respect for others. It would not be out of place for Churches to teach their members the essentials of interpersonal and group communication as veritable tools for conflict resolution. Christians ought to continue serious denominational dialogue (ecumenism) (Omonokhua, 2018). Conflict resolution should not be 
initiated in a way that it would leave some negative consequences where one party feels they have been defeated but should aim at bringing about the glory of God (Folarin, \& Adelakun, 2016, p.283).

- Embracing Respect and Tolerance for the Creed of Others: There is no question about respect and tolerance for the creed of others. Increased awareness about what the other person from another Church believes is key to entrenching infra-faith relations amongst Christians. It is the obligation of religious leaders to preach and live infra-faith cohesion. Perhaps government needs to be active in its role of monitoring and sanctioning hate preaching. It is safe to say that learning about other people's faith is crucial to embracing the lessons of ecumenism and Christian unity.

- Training and Retraining of Clerics: It is the responsibility of the Church to train and retrain its leaders. In a changing world marked by advances in Information and Communications Technologies (ICT) leading to explosions in social media platforms, Christians cannot be unmoved by these changes. In line with Jesus who prayed and fasted before choosing his apostles and also trained them for three years before departing to his Father, the Church must take the leadership question seriously. This entails the training and retraining of Church personnel (Catholic Bishops' Conference of Nigeria, 2004, p. 39 \& Akin-John, 2018) of Church personnel in line with the mission of Christ vis-à-vis international best practices. Since education is expensive, it is incumbent on the people of God to support the training of their leaders. This is a noble responsibility.

- Leadership Based on Merit: To further address the leadership question which appears to be the bane of the Church in Nigeria, the twin evils of tribalism and nepotism have to be shown red card if the Church is to reach its full potentials. Be it internally within a Church or CAN, prospective leaders should be vying for positions in order to serve. In that way, a template for merit would have been created. Merit means considering factors such as, is he qualified, is he the man for the job, can he deliver? These parameters are indicators of a Church on the part of growth. Dairo insists that God's servants must be qualified spiritually and properly trained as well as possess organisational ability (p.87).

- Ensuring Feedback Mechanism: Based on the Community Score Card strategy, feedback is one mechanism that Service-Providers hate. In fact, no one likes feedback. However, to entrench infra-faith cohesion amongst Christians in Nigeria, there has to be mature and sincere "supportive feedback" (Folarin \& Adelakun, 2016, p.279) between Christian leaders and their followers. Once in place, feedback helps Service-Users to hold Service- Providers accountable. It assists in resolving the poor and unequal relations between the two. It also helps in improving tangible services like infra-faith unity leading to Joint Action Plans (Muyumbu 2018). This requires creating models of creative listening and clear communication within churches, ecumenical organisations and at flashpoints in various communities (Kobia 2005). As such, feedback can never be dispensed with (CARE Malawi, 2013, p. 11).

- Reinforcing Focused Group Communication: Given the importance of group communication in the life of every group or organisation, it is crucial for all who hope to engage in any meaningful infra-faith cohesion to use the group communication model. This allows for free social and spiritual exchanges as well as feedback among participants in a group which further engenders meaningful dialogue leading to peaceful coexistence in the community and larger society as we saw.

\subsection{Conclusion}

We have seen that group communication is a sine qua non for assessing intra-faith cohesion in Nigeria. It was also established that the quality of leadership in the Church in Nigeria has been compromised by leadership tussle based on tribalism and nepotism as well as a prosperity gospel which insists on preaching materialism over repentance. The paper established that the unfortunate mentality of holier-than-thou attitude and name-calling among Christians in the country arises as a result of lack of teaching the gospel of Christ premised on salvation of souls. Participants had also blamed the issues of doctrinal difference, poor discipleship and discrimination of women on the highhandedness of leaders who wield so much power without the corresponding accountability that goes with it. 
Bearing in mind the limitation of the paper namely, that it is not exhaustive about the subject matter, creation of awareness, education and deliberate attempts at respecting others are necessary ingredients for infra-faith relations. Initiatives such as the Supporting Leaders Nigeria (SLN) Programme delivered by The Kukah Centre et al should not only be lauded but supported by the government and other well-meaning Nigerians. This is why all stakeholders must put hands on deck to assist these Non-Governmental Organisations (NGOs) in providing religious leaders and members of various communities across the country with the requisite skills and tools to identify and tackle religious extremism, initiate counter-narratives for practical community action and strengthen social cohesion.

To achieve this, it is crucial for all Christians in Nigeria to go back to the drawing board and relive the experience of the Church as oikos, meaning "house" being the root word for oikoumene, that refers to the inhabited world, which in turn became the English word "ecumenical" (Jesson, 2003, p.15). Since the youth are the leaders of tomorrow, it behoves parents and the Christian community to train them in the way of mutual respect, tolerance and leadership in the Church and society. Because respect for the religious sensibilities of others starts from the home, it should be reinforced on the pulpit and in schools. In that way, intra-faith cohesion in Nigeria can be assessed and sustained by all.

\section{ACKNOWLEDGEMENTS}

The credit for this paper goes to The Kukah Centre, Tony Blair Institute for Global Change and Care International UK, Development Initiative for West Africa for funding the intra-faith workshop and providing the researcher with the platform to conduct the survey.

\section{REFERENCES}

[1] Achebe, C. (1983). The trouble with Nigeria. London: Heinemann.

[2] Akin-John, F.B (2018). Why we need to train and retrain pastors.www.tribuneonlineng.com/85844/. Accessed 2/7/2019.

[3] Alabi, C (2017). Leadership tussle: Assemblies of God Church leaders declare general council in north. www.dailytrust.com.ng/news/general/leadership-tussle-assemblies-of-god-church-leaders-declare-generalcouncil-in-north/193364.html. Accessed 2/6/2019.

[4] CARE Malawi (2013). "The Community Score Card (CSC): A generic guide for implementing CARE's CSC process to improve quality of services." Cooperative for Assistance and Relief Everywhere, Inc.

[5] Catholic Bishops' Conferences of Nigeria (2004). I chose you: The Nigerian priest in the third millennium. Catholic Secretariat of Nigeria, Abuja, Nigeria.

[6] Dairo, A.O (2004). Church leadership in Nigeria in the light of leadership qualification in Timothy 3:1-7. Research on Humanities and Social Sciences. Vol. 4. No.6 [84-88].

[7] Danbaba, D. (2016). Church leadership tussle: Its implication for the growth of Evangelical Church Winning All (ECWA) in Kaduna State. Masters Dissertation, Department of Arts and Social Science Education, Faculty of Education, Ahmadu Bello University, Zaria, Kaduna State, Nigeria.

[8] Dyikuk, J. J (2011). The Pew and the Pulpit: Homiletics in the light of social communications and collaborative ministry. Fingerprints: Kaduna.

[9] Dyikuk, J.J (2018) An appraisal of communication as liturgy: Igwebuike: An African Journal of Arts and Humanities Vol. 4, No 5.[62-85].

[10] Ebhomele, E. (2017). Nigerians react as supreme court boots out Rev. Emeka from Assemblies of God Church. www.naija.ng/1090359-supreme-court-rules-rev-emeka-assemblies-god-churchs-tussle.html. Accessed 2/2/2019.

[11] Folarin, G.O \& Adelakun, A.J (2016). Multi-dimensional approach to crisis management in the church. European Scientific Journal. Vol.12.No.23 [270-288].

[12] Gombe State Government White Paper Draft (2014). Consolidated Reports on conflicts in Gombe Southern Senatorial District.

[13] Inja, T. (2012). Full-cycle, Catholicism to Pentecostalism: Similarities among Nigerian churches as a plus for ecumenism. International Journal of Theology \& Reformed Tradition. Vol 4. [194-208].

[14] Jesson, N.A. (2003). Doctrine divides, service unites: Towards a vital and coherent theology. Toronto: University of St. Michael's College.

[15] Joshua, R. M (2016). State intervention and communal conflicts in Gombe State: A study of selected cases. Masters Dissertation, Department of Public Administration, Ahmadu Bello University, Zaria, Kaduna State, Nigeria. 
[16] Kobia, S (2005). Challenges facing the ecumenical movement in the $21^{\text {st }}$ century - Being a keynote address at the Inter Church Centre, New York, 22 October, 2005. www.oikoumene.org/en/resources/ documents/wcc-programmes/ecumenical-movement-in-the-21st-century/foundstional/texts/challengesfacing-the-ecumenical-movement-in-the-21st-century. Accessed 2/7/2019.

[17] Majekodumi, S (2014). Catholic Bishop faults CAN President. www.news2.onlinenigeria.com/news/ 379732-catholic-bishop-faults-can-president.html. Accessed 2/7/2019.

[18] Mohammed, A. (2016). CAN wants ministry for religious affairs in Gombe. www.dialytrust.com.ng /news/gombe/can-wants-ministry-for-religious-affairs-in-gombe/127819.html. Accessed 2/7/2019.

[19] Muyumbu, G. (2018). JCAP Facilitator's Handbook - Supporting Leaders Nigeria (SLN) Project. CARE International Tony UK \& Blair Institute for Global Change. London: United Kingdom.

[20] Nmah, P. (2015). A coat of many doctrinal controversies: An X-ray of Nigerian Christian spirituality. Mediterranean Journal of Social Sciences. Vol 6. No. 3 S2. [367-372].

[21] Okoli. A.C \& Uhembe, A.C. (2014). Materialism and commodification of the sacred: A political economy of spiritual materialism in Nigeria. European Scientific Journal. Vol. 10. No. 14. [595-606].

[22] Olowolagba, F. (2018). Ahiara diocese: Catholic bishop, Okpalaeke. www.dailypost.ng/2018/02/19/ahiaradiocese-catholic-bishop-okpalaeke-resigns/. Accessed 2/7/2019.

[23] Omonokhua, C.A (2018). Ecumenical dialogue. www.carefronting.or/ecumenical-dialogue/. Accessed $2 / 5 / 2019$

[24] Owete, F (2014). Northern minorities protest 'marginalisation' by Hausa-Fulani. www.premiumtimesng .com/news/161512-northern-minorities-protest-marginalisation-hausa-fulani.html. Accessed 2/7/2019.

[25] Tony Blair Institute \& CARE International UK (2018). PPT 2 - Methodology in the community score card. Abuja: Nigeria.

[26] 24 Ureports.com (2018). Bishop of Lagos: Crisis looms in Anglican Church, aggrieved parties allege bribery. www.247ureports.com/bishop-lagos-crisis-anglican-church-aggrieved-parties-allege- bribery/. Accessed 2/7/2019.

[27] World Council of Churches (2018). What is the World Council of Churches? www.oikoumene.org/ en/about-us. Accessed 2/7/2019.

Citation: Justine John Dyikuk. "Assessing Intra-Faith Cohesion in Nigeria through Group Communication: The Gombe Community Score Card Project!". International Journal of Media, Journalism and Mass Communications (IJMJMC), vol 5, no. 1, 2019, pp. 16-27. doi:http://dx.doi.org/10.20431/2455-0043.050 1002

Copyright: (C) 2019 Authos. This is an open-access article distributed under the terms of the Creative Commons Attribution License, which permits unrestricted use, distribution, and reproduction in any medium, provided the original author and source are credited. 